\title{
Evaluation of Nutritional and Sensory Properties of Cocoa Pulp Beverage Supplemented with Pineapple Juice
}

\author{
Afolabi, M. O. ${ }^{1}$, Ibitoye, W. O. ${ }^{1} \&$ Agbaje, A. F. ${ }^{1}$ \\ ${ }^{1}$ Department of Food Science and Technology, Bowen University, Iwo, Osun State, Nigeria
}

Correspondence. Afolabi, M. O., Department of Food Science and Technology, Bowen University, Iwo, Osun State, Nigeria. E-mail address: afolabiolutoyin@yahoo.com

\author{
Received: March 16, 2015 Accepted: June 4, 2015 Online Published: November 11, 2015 \\ doi:10.5539/jfr.v4n6p58 URL: http://dx.doi.org/10.5539/jfr.v4n6p58
}

\begin{abstract}
One of the major unutilized by-products of cocoa is cocoa mucilage (pulp). Cocoa pulp can be fortified with nutrients such as vitamins from other sources or the juice can be blended with other fruit juices from fruits such as pineapple that are good sources of vitamins. The objective of this study is to produce Cocoa pulp beverage supplemented with pineapple juice. Cocoa Pulp (CP) was used to replace Pineapple juice (PJ) at 0, 50, 60 70, 80, 90 and $100 \%$ levels. The nutritional and sensory properties of the CP+PJ beverages were evaluated. The CP beverage contained increasing levels of calcium, iron, fat and phosphorus with increased levels of $\mathrm{CP}$ in the blend but lower amounts of protein, carbohydrates and vitamin $\mathrm{C}$ than the $\mathrm{PJ}$. In the $\mathrm{CP}+\mathrm{PJ}$ blends there were not any significantly effect on the $\mathrm{pH}$, ash and crude fiber contents. However, Titratable Acidity increased from 5.43 to $5.92 \%$. Of all the blends, the $50 \% \mathrm{PJ}$ mixture received the best evaluation from panelists-higher sensory ratings-next to the $100 \% \mathrm{PJ}$ that was the best performer in the tests. Incorporation of cocoa pulp in the new beverages added value to the cocoa by-product and offers new options of easy, convenient and highly nutritive beverages for children and adult at the local level.
\end{abstract}

Keywords: beverage, nutrients, sensory properties, cocoa pulp-pineapple juice

\section{Introduction}

Cocoa (Theobroma cacao) is known for its beans all over the world with Nigeria being one of the major producers. From the findings of Asiedu (1991), cocoa beans contain about 50\% fat. According to Adomako (1974) and International Cocoa Organization (2006), the utilization of cocoa is only $10 \%$ of the gross weight of cocoa pod; and one of the problems that remain unsolved by cocoa producing countries is finding economic use for the by-products of cocoa. One of the major unutilized by-products is cocoa mucilage (pulp); cocoa pulp is a sweet, viscous liquid surrounding the cocoa beans within the pod. On breaking the pod and extracting the beans, the mucilage flows out. Cocoa pulp is free of alkaloids and other toxic substances and does not easily get these substances on heating. Leung (1980) reported glucose (11\%) and pectin (5\%) as the two major constituents of the total dry matter $(15.8 \%)$ of the mucilage. Reports by Opeke (2005) stated that compared to commonly consumed orange and pineapple juices, cocoa pulp is a good source of calcium, iron, fat and phosphorus but a poor source of vitamins, protein and carbohydrate. Cocoa juice can be fortified with nutrients such as vitamins from other sources or the juice can be blended with other fruit juices from fruits such as pineapple that are good sources of such nutrients. According to Paul (1975) and Smith (1993), pineapple is rich in vitamins B1, B2, B6 and $\mathrm{C}$ and a good source of minerals such as magnesium. Study by FAO showed that pineapple is a good source of Bromelin (a protein-digesting enzyme) and natural fiber. Pineapple is described by FAO as having an attractive flavour and refreshing sugar-acid balance. The objective of this study is to evaluate the nutritional and sensory properties of cocoa pulp beverage supplemented with pineapple juice and to investigate the health benefits of the beverage blend to the rural communities of the cocoa growing countries.

\section{Materials and Methods}

\subsection{Source of Materials}

Cocoa (Theobroma cacao) pods were obtained from a farm in Kila, Ogun state of Nigeria. Pineapple (Ananas comosus) fruits were gotten from Iwo market in Osun state, Nigeria. Cocoa pulp juice: Greenish yellow cocoa pods were selected from the lots. They were thoroughly washed and broken into halves to remove the fresh 
beans surrounded by the pulp. The pulp was extracted from the beans at $25^{\circ} \mathrm{C}$ and filtered using a sterile muslin cloth. It was pasteurized at $62^{\circ} \mathrm{C}$ for 15 minutes and hot filled into sterilized bottles, allowed to cool and then refrigerated at $4^{0} \mathrm{C}$.

Pineapple Juice: freshly harvested pineapple fruits were sorted and washed. The fruits were peeled, washed and blended to pulp and sieved using muslin cloth. The juice obtained was pasteurized at $62^{\circ} \mathrm{C}$ for 15 minutes, hot filled into sterilized bottles, allowed to cool and then refrigerated at $4^{0} \mathrm{C}$.

Cocoa-pulp/ Pineapple juice beverage: The pineapple juice $(10,20,30,40$ and 50\%) was blended with cocoa-pulp juice on replacement basis in a Kenwood food blender operated at full speed for $10 \mathrm{~min}$. The resulting mixture was boiled (for 5 minutes) in an aluminum pot with a lid. The beverage samples $(500 \mathrm{ml})$ were hot filled into sterile bottles $\left(1 \mathrm{~cm}\right.$ head space). The samples were cooled to a temperature of $25^{\circ} \mathrm{C}$ and then stored in a refrigerator of $10 \pm 2^{0} \mathrm{C}$ until used.

\subsection{Sensory Evaluation}

Cocoa-pulp, pineapple juice and blends obtained from them were evaluated for color, flavor, taste and overall acceptability by twenty trained judges as described by Ihekoronye and Ngoddy (1985). The samples were evaluated on 9-point hedonic scale $(1=$ dislike extremely and $9=$ like extremely $)$. The panel members consisted of staff and students randomly selected from the University Community.

\subsection{Analytical Methods}

$\mathrm{pH}$ was determined with a digital $\mathrm{pH}$ meter (model $350 \mathrm{pH}$ meter, Jenway) at ambient temperature $\left(30 \pm 2^{\circ} \mathrm{C}\right.$ ) Solublesolids (Brix) were measured using refractometer. Titratable acidity (\% citric acid) was determined using A.O.A.C (2000) method. Protein (Micro Kjeldahl, NX6.25), fat, ash, crude fibre and moisture were determined by A.O.A.C. (2000) methods. Carbohydrate was calculated by difference $(100-(\%$ protein $+\%$ fat $+\%$ moisture + \%fiber). Vitamin $\mathrm{C}$ was determined by the 2,6-dichloroindophenol titration methods (A.O.A.C,2000).Calcium ,Potassium and Sodium were determined using flame photometer (model: Cole partner instrument Company, Chicago, Illinois 6006). Iron was determined by Atomic Absorption spectroscopy using Alpha 4 atomic absorption spectrophotometer, (Cole partner instrument company, Chicago.)

Phosphorus content was determined using the methods described by Tahir and Sumati (2009) and Raun et al. (1987).

\subsection{Statistical Analysis}

All data obtained were subjected to statistical analysis of variance (ANOVA) using SPSS $(15.0,2005)$ means were separated using turkey test with level of significance of $\mathrm{P}<0.05$.

\section{Results and Discussion}

The proximate composition of pineapple juice (PJ), Cocoa pulp juice (CP) and their blends are presented in Table 1.The cocoa pulp beverage contained higher amounts of fat and ash but lower amounts of protein, carbohydrates and crude fibers than pineapple juice. The compositional values for $\mathrm{PJ}$ and $\mathrm{CP}$ were in agreement with the values reported by Asiedu (1991) and Smith (1993). The protein, carbohydrate and crude fiber contents of CP-PJ beverages decreased while fat and ash contents increased with increased levels of cocoa pulp.

Table 1. Proximate composition of cocoa pulp juice supplemented with pineapple juice

\begin{tabular}{ccccccc}
\hline Sample codes & $\begin{array}{c}\text { Moisture } \\
\text { Content }(\%)\end{array}$ & $\begin{array}{c}\text { Carbohydrate } \\
\%\end{array}$ & $\begin{array}{c}\text { Protein } \\
\%\end{array}$ & $\begin{array}{c}\text { Ash } \\
\%\end{array}$ & $\begin{array}{c}\text { Fat } \\
\%\end{array}$ & $\begin{array}{c}\text { Crude fiber } \\
\%\end{array}$ \\
\hline $100 \%$ Cocoa Pulp & $93.5 \pm 03^{\mathrm{a}}$ & $4.10 \pm 05^{\mathrm{c}}$ & $0.53 \pm 0.06^{\mathrm{d}}$ & $0.87 \pm 0.06^{\mathrm{a}}$ & $1.00 \pm 0^{\mathrm{a}}$ & $0.47 \pm 0.58^{\mathrm{bc}}$ \\
$100 \%$ Pineapple & $93.0 \pm 0.11^{\mathrm{a}}$ & $4.67 \pm 0.58^{\mathrm{a}}$ & $1.03 \pm 0.06^{\mathrm{a}}$ & $0.70 \pm 01^{\mathrm{b}}$ & $0.57 \pm 0.06^{\mathrm{c}}$ & $0.90 \pm 0.1^{\mathrm{a}}$ \\
$90 \%$ Cocoa Pulp & $93.0 \pm 0.05^{\mathrm{a}}$ & $4.20 \pm 0.13^{\mathrm{c}}$ & $0.83 \pm 0.06^{\mathrm{bc}}$ & $0.70 \pm 03^{\mathrm{b}}$ & $0.73 \pm 0.06^{\mathrm{b}}$ & $0.40 \pm 03^{\mathrm{c}}$ \\
$80 \%$ Cocoa Pulp & $93.1 \pm 0.13^{\mathrm{a}}$ & $4.47 \pm 0.06^{\mathrm{b}}$ & $0.80 \pm 0.07^{\mathrm{bc}}$ & $0.73 \pm 0.06^{\mathrm{b}}$ & $0.73 \pm 0.06^{\mathrm{b}}$ & $0.43 \pm 0.06^{\mathrm{bc}}$ \\
$70 \%$ Cocoa Pulp & $93.4 \pm 0.32^{\mathrm{a}}$ & $4.47 \pm 0.06^{\mathrm{b}}$ & $0.73 \pm 0.06^{\mathrm{bc}}$ & $0.73 \pm 0.06^{\mathrm{b}}$ & $0.80 \pm 0^{\mathrm{b}}$ & $0.53 \pm 0.06^{\mathrm{bc}}$ \\
$60 \%$ Cocoa Pulp & $93.2 \pm 0.30^{\mathrm{a}}$ & $4.53 \pm 0.06^{\mathrm{ab}}$ & $0.73 \pm 0.06^{\mathrm{bc}}$ & $0.70 \pm 0.12^{\mathrm{b}}$ & $0.80 \pm 0^{\mathrm{b}}$ & $0.57 \pm 0.06^{\mathrm{bc}}$ \\
$50 \%$ Cocoa Pulp & $93.3 \pm 0.07^{\mathrm{a}}$ & $4.57 \pm 0.06^{\mathrm{ab}}$ & $0.67 \pm 0.06^{\mathrm{c}}$ & $0.80 \pm 07^{\mathrm{ab}}$ & $0.80 \pm 0^{\mathrm{b}}$ & $0.67 \pm 0.12^{\mathrm{b}}$ \\
\hline The values represent the mean of the triplicates of each sample. Mean values carrying the same letters along the same column are not
\end{tabular}

The values represent the mean of the triplicates of each sample. Mean values carrying the same letters along the same column are not significantly different. 
The chemical compositions of the $\mathrm{PJ} / \mathrm{CP}$ were presented in Table 2; cocoa pulp (CP) beverage contained higher calcium, iron and phosphorus but lower vitamin $\mathrm{C}$ contents than pineapple juice beverage. The addition of pineapple juice diluted the concentration of calcium, iron, and phosphorus while increasing the concentration of Vitamin C in the blends; this is in agreement with the finding of Smith (1993). The higher levels of phosphorus, calcium and iron accounted for higher ash content in cocoa pulp juice. The metabolic functions of minerals and vitamins have been extensively reported by Ihekoronye and Ngoddy (1985); phosphorus provides strength to bones and teeth and is very potent in performing essential activities for different body parts like brain, kidney, heart and blood. Phosphorus works in association with calcium for healthy bones, gum and tooth enamel; calcium is also an important constituent of body fluid. Iron is required in mamalian nutrition to prevent anemia. Vitamin $\mathrm{C}$ is an antioxidant vitamin capable of neutralizing potentially damaging free radicals in the blood. It is also required for formation of collagen and absorption of iron from plant source. National Academy of Sciences (2002) RDA for adult males and females are $1000 \mathrm{mg}$ calcium each, $700 \mathrm{mg}$ phosphorus each, $8 \mathrm{mg}$ and $18 \mathrm{mg}$ iron, respectively and $75 \mathrm{mg}$ and $90 \mathrm{mg}$ vitamin $\mathrm{C}$ respectively per day. Results show in the beverage blends that phosphorus, calcium, iron and vitamin $\mathrm{C}$ contribution to RDA ranges from $6.1-7.1 \%, 4.2-5.0 \%, 3.2-17.9 \%$ and $55.6-90.0 \%$ in adults if $250 \mathrm{ml}$ of beverage blends is taken daily. The low crude fiber content of the CP-PJ beverage at higher concentrations of cocoa-pulp makes them digestible foods especially for children and enhances nutrient availability. Variations in the $\mathrm{pH}$ of CP-PJ blends (4.00-4.17) were not significant $(\mathrm{p}>0.05)$. The titratable acidity increased from 5.43 to $5.47 \%$ citric acid; this will have positive implications for the storage qualities of the CP-PJ products.

Table 2. Mean values for chemical analysis of the juice blends

\begin{tabular}{|c|c|c|c|c|c|c|c|}
\hline Parameter & $\begin{array}{c}100 \% \text { Cocoa } \\
\text { Pulp }\end{array}$ & $\begin{array}{c}100 \% \\
\text { Pineapple }\end{array}$ & $\begin{array}{c}90 \% \text { Cocoa } \\
\text { Pulp }\end{array}$ & $\begin{array}{c}80 \% \text { Cocoa } \\
\text { Pulp }\end{array}$ & $\begin{array}{c}70 \% \text { Cocoa } \\
\text { Pulp }\end{array}$ & $\begin{array}{c}60 \% \text { Cocoa } \\
\text { Pulp }\end{array}$ & $\begin{array}{c}50 \% \text { Cocoa } \\
\text { Pulp }\end{array}$ \\
\hline $\begin{array}{l}\text { Ascorbic Acid } \\
\text { (mgA.A/100ml) }\end{array}$ & $12 \pm 1.21^{\mathrm{f}}$ & $30.3 \pm 1.12^{\mathrm{a}}$ & $20 \pm 0^{\mathrm{e}}$ & $21.0 \pm 0^{\mathrm{d}}$ & $23.3 \pm 0.58^{\mathrm{c}}$ & $25.2 \pm 0.58^{\mathrm{b}}$ & $26.7 \pm 0.58^{\mathrm{ab}}$ \\
\hline Calcium (mg/100ml) & $24 \pm 1.73^{\mathrm{a}}$ & $15.8 \pm 0.58^{\mathrm{cd}}$ & $20 \pm 02^{\mathrm{b}}$ & $18.7 \pm 1.15^{\mathrm{bc}}$ & $17.71 \pm 0.58^{\mathrm{bc}}$ & $17.3 \pm 0.58^{\text {cd }}$ & $16.7 \pm 0.58^{\mathrm{bc}}$ \\
\hline Iron $(\mathrm{mg} / 100 \mathrm{ml})$ & $1.22 \pm 0.58^{\mathrm{a}}$ & $0.23 \pm 09^{\mathrm{d}}$ & $0.57 \pm 0.58^{\mathrm{b}}$ & $0.41 \pm 0.01^{\mathrm{c}}$ & $0.33 \pm 0.01^{\mathrm{cd}}$ & $0.30 \pm 07^{\mathrm{cd}}$ & $0.23 \pm 0.58^{\mathrm{d}}$ \\
\hline Phosphorus (mg/100ml) & $30 \pm 01^{\mathrm{a}}$ & $16.0 \pm 05^{\mathrm{d}}$ & $20 \pm 09^{\mathrm{a}}$ & $18.7 \pm 1.15^{\mathrm{bc}}$ & $17.7 \pm 0.58^{\text {cd }}$ & $17.3 \pm 0.58^{\mathrm{d}}$ & $17.20 \pm 0.05^{\mathrm{d}}$ \\
\hline $\mathrm{pH}$ & $3.87 \pm 0.06^{\mathrm{c}}$ & $4.0 \pm 11^{\mathrm{b}}$ & $4.14 \pm 10^{\mathrm{ab}}$ & $4.17 \pm 0.06^{\mathrm{a}}$ & $4.17 \pm 0.06^{\mathrm{a}}$ & $4.17 \pm 0.06^{\mathrm{a}}$ & $4.12 \pm 02^{\mathrm{ab}}$ \\
\hline Titratable Acidity(\%) & $5.92 \pm 0.06^{\mathrm{a}}$ & $5.63 \pm 0.06^{\mathrm{d}}$ & $5.7 \pm 20^{\mathrm{d}}$ & $5.7 \pm 07^{\mathrm{b}}$ & $5.67 \pm 15^{\mathrm{d}}$ & $5.53 \pm 20^{\mathrm{cd}}$ & $5.43 \pm 0.06^{\mathrm{c}}$ \\
\hline Total soluble Solids(\%) & $11.47 \pm 0.06^{\mathrm{c}}$ & $12 \pm 19.21^{\mathrm{a}}$ & $11.37 \pm 27^{\mathrm{d}}$ & $11.49 \pm 03^{\mathrm{d}}$ & $11.43 \pm 08^{\mathrm{d}}$ & $11.62 \pm 10^{\mathrm{bc}}$ & $11.71 \pm 04^{\mathrm{ab}}$ \\
\hline
\end{tabular}

The values represent the mean of the triplicate of each sample. Mean values carrying the same letters along the same row are not significantly different.

The mean sensory scores of pineapple juice (PJ) and cocoa pulp juice (CP) and their blends are presented in Table 3. At all levels of pine apple juice addition, the sensory scores of CP-PJ beverages for all the attributes appreciably increased with an increase in the levels of PJ. However, the CP-PJ beverages blends at 30, 40 and $50 \%$ pineapple juice showed no significant differences $(\mathrm{p}>0.05)$ in overall acceptability scores. Beverage blend containing 50\% pineapple juice received the next highest score (7.33) to $100 \%$ pineapple juice (8.25) and the scores are not significantly different $(\mathrm{p}>0.05)$.

Table 3. Sensory profile for cocoa pulp and pineapple juice blends

\begin{tabular}{|c|c|c|c|c|c|c|c|}
\hline Parameter & $\begin{array}{c}100 \% \text { Cocoa } \\
\text { Pulp }\end{array}$ & $\begin{array}{c}100 \% \\
\text { Pineapple }\end{array}$ & $90 \%$ Cocoa Pulp & $\begin{array}{c}80 \% \text { Cocoa } \\
\text { Pulp }\end{array}$ & $\begin{array}{c}70 \% \text { Cocoa } \\
\text { Pulp }\end{array}$ & $\begin{array}{c}60 \% \text { Cocoa } \\
\text { Pulp }\end{array}$ & $\begin{array}{c}50 \% \text { Cocoa } \\
\text { Pulp }\end{array}$ \\
\hline Color & $5.75 \pm 1.10^{c}$ & $8.17 \pm 0.80^{\mathrm{a}}$ & $6.42 \pm 1.2^{\mathrm{bc}}$ & $6.83 \pm 1.2^{\mathrm{bc}}$ & $6.83 \pm 0.83^{\mathrm{bc}}$ & $7.18 \pm 1.22_{\mathrm{ab}}$ & $7.5 \pm 1.23^{\mathrm{ab}}$ \\
\hline Flavor & $5.83 \pm 0.82^{\mathrm{b}}$ & $7.58 \pm 0.83^{\mathrm{a}}$ & $6.58 \pm 0.92^{\mathrm{ab}}$ & $6.67 \pm 1.4^{\mathrm{ab}}$ & $6.92 \pm 0.11^{\mathrm{ab}}$ & $7.17 \pm 1.43^{\mathrm{ab}}$ & $7.25 \pm 1.26^{\mathrm{ab}}$ \\
\hline Taste & $5.92 \pm 0.72^{\mathrm{b}}$ & $7.83 \pm 0.91^{\mathrm{a}}$ & $6.83 \pm 0.71^{\mathrm{ab}}$ & $6.92 \pm 1.7^{\mathrm{ab}}$ & $7.08 \pm 1.31^{\mathrm{ab}}$ & $6.75 \pm 1.63^{\mathrm{ab}}$ & $7.25 \pm 1.61^{\mathrm{ab}}$ \\
\hline Overall & $6.08 \pm 0.79^{\mathrm{b}}$ & $8.25 \pm 0.87^{\mathrm{a}}$ & $6.83 \pm 0.72^{\mathrm{ab}}$ & $6.92 \pm 1.7^{\mathrm{ab}}$ & $6.92 \pm 0.10^{\mathrm{ab}}$ & $7.17 \pm 1.54^{\mathrm{ab}}$ & $7.33 \pm 1.53^{\mathrm{ab}}$ \\
\hline
\end{tabular}

The values represent the mean of the triplicates of each sample. Mean values carrying the same letters along the same row are not significantly different. 


\section{Conclusion}

The combination of pineapple juice and cocoa bean pulp resulted in beverages with improved nutrients composition compared to their respective components. The cocoa pulp/pineapple juice beverage containing $50 \%$ pineapple juice were generally accepted and were not significantly different from $100 \%$ pineapple juice with respect to the sensory attributes studied. The use of fresh cocoa pulp/pineapple juice should be promoted for utilization of cocoa pulp and for the nutrient potential of the beverage blend particularly vitamins, calcium, iron and phosphorus. The beverage can be consumed by children and adults to increase nutrient intake. The production of the beverage will also increase rural employment and income and thus reduce poverty level since the technology involved can easily be applied by cocoa farmers and other interested investors.

\section{References}

Adomako, D. K. (1974). Production of Cocoa by-products from fresh cocoa pods wastes and non-traditional products from cocoa beans. Cocoa Research Institute of Ghana, Technical bulletin, No 14.

AOAC. (2000). Official methods of Analysis of Association of Analytical chemists, AOAC international, $17^{\text {th }}$. In W. Horowitz (ed.), AOAC intern Maryland Ch, Vols 1 and 2, 45, 112-120.

Asiedu, J. J. (1991). Transformation of tropical zone agricultural products. CTA Karthala.

Chikwendu, J. N., \& Obizoba, I. C. (2004). Chemical, microflora and sensory evaluation of priorities based on processed and unprocessed ground bean and maize flour blends. Proceeding. Nutr. Soc. Nig. Pp. 97-108.

Food and Agricultural Organization. (1993). Repertoir general of the ailment volume 3.Table of composition exotic fruits of cuilete of Africa, Your Doc. Lavoisier.

Ihekoronye, I. A., \& Ngoddy, P. O. (1985). Integrated food Science and Technology for the tropics (pp. 60-134). Macmillan London.

International Cocoa Organization. (I.C.C.O). ( 2006).Technical Report of I.C.C.O. executive committee on a pilot plant to process cocoa by products in Ghana. International cocoa organization secretariat, London WC2A $1 N U$, U.K.

Leung, A. Y. (1980). Encyclopedia of common natural ingredients used in food, drugs and cosmetics. John Wiley and sons, New York.

National Academy of Sciences. (2002). Dietary Reference Intakes for Energy, Carbohydrates, Fibre, Fat, Fatty acids, Cholesterol, Protein, and Acids. Food and Nutrition Board,Washington D. C., National Academic Press.

Opeke, L. K. (2005). Spectrum books limited, Ibadan (pp. 89-93, 164-171).

Paul, J. K. (1975). Fruits and vegetables juice processing (p. 69). Noyes Data Corporation. USA.

Raun, W. R., Olson, R. A., Sander, D. H., \& Westerman, R. L. (1987). Alternate Procedure for total Phosphorus determination in plant tissue. Communication in soil science and plant Analysis, 18(5), 543-557. http://dx.doi.org/10.1080/00103628709367840

Smith, L. G. (1993). Pineapples. In Encyclopedia of food Science, Technology and Nutrition. Edited by Macrae R. et al. vol. 6. p. 3598-3604.

Tahir, A., \& Sumati, N. (2009). Manual of Soil, Plant and Water Analyses (pp. 130-140). Daya Publishing house, India.

\section{Copyrights}

Copyright for this article is retained by the author(s), with first publication rights granted to the journal.

This is an open-access article distributed under the terms and conditions of the Creative Commons Attribution license (http://creativecommons.org/licenses/by/3.0/). 